\title{
An Empirical Study of Seasonal Rainfall Effect in Calabar, Cross River State, Nigeria.
}

\author{
UDOIMUK, A. B. ${ }^{\text {B }}$, OSANG, J. E. ${ }^{\text {A, }}$, ETTAH, E. B. ${ }^{\text {A }, ~, U S H I E, ~ P . ~ O . ~}{ }^{\text {A }}$, \\ EGOR, A. O. ${ }^{A}$, ALOZIE, S. I.

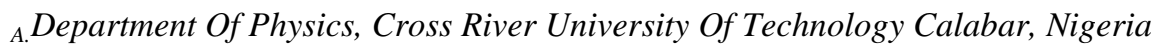 \\ ${ }_{B . D e p a r t m e n t}$ Of Physics, University Of Calabar, Calabar. \\ c. Department Of Physics, Abia State University, Uturu, Abia State, Nig.
}

\begin{abstract}
Calabar has been experiencing yearly severe flooding and landslides within and around the metropolis with substantial costs, in terms of loss of lives and destruction of properties. This paper is focus on the empirical study of seasonal rainfall effect in Calabar, Nigeria. Data was gathered through a well designed and articulated oral and written questionnaires, direct and first-hand observation of the environment, and comprehensive interview sessions were carried out with randomly selected Landlords. A total of thirteen thousand $(13,000)$ questionnaires were randomly distributed evenly to some Landlords in twenty six (26) streets of the study Area from January 2012 to October 2013. Twelve thousand four hundred and eigty two $(12,482)$ valid questionnaire were received back. Twelve thousand $(12,000)$ of the inhabitant Landlords reported that, they were not affected negatively. Table 2 shows the total number of buildings that were negatively affected due to flooding in the Area. While rainfall data from 1993-2012 were collected from the Nigeria Meteorological Station(NIMET), Calabar. A simple descriptive analysis was used. The results shows that, rainfall is one of the Climatic factor that can indicate Climate change and has created ecological destabilization and altered the pattern of the vegetation belt especially in the flood prone areas highlighted, which includes Atimbo, Edim otop, Ekpo Abasi, Ndidem Usang Iso, Goldie, Target, Ebito, Big Qua, Edibe Edibe, Atamunu, Akim Road, Otop Abasi and Ikot Eyo by Paliamentary Road (Calabar). The rainfall pattern has also enhanced wind erosion/desertification, soil erosion and coastal flooding in Calabar. With these impacts, the paper therefore recommends some adaptive and mitigation measures that could help to revert the current situation, otherwise properties and lives will continue to be lost. Keywords: rainfall pattern, climate change, flooding, vegetation belts, erosion, shift and land slides
\end{abstract}

\section{Introduction}

Calabar has been experiencing yearly severe flooding and landslides within and around the metropolis with substantial costs, in terms of loss of lives and destruction of properties caused by rainfall. Rainfall is a climate parameter that affects the way and manner man lives. It affects every facet of the ecological system, flora and fauna inclusive. Hence, the study of rainfall is important and cannot be over emphasized (Obot et al 2010), (Osang et al 2013). Combination of high temperatures due to global warming and high humidity of the humid tropical climate are responsible for recurring flood in Calabar, the capital of Cross River State (Udo et al 2002), (Osang et al 2013). Researchers seems to be more comfortable with working on such parameters as total rainfall, extreme intensity, extreme frequency, extreme event and total rain days when dealing with rainfall data. Though the proportional contribution from extreme events to the total rain fall depends on the method used to calculate the index. An increase in the number of rain days often increases with total rainfall and extreme frequency (Udo et al 2002), (Obot et al 2010), (Osang et al 2013).

Water is health and health is water. Humans rely on water for everything and thus water is one of the essential resources for human survival (Agbor et all 2013). The main source of water is rain. Rain is liquid water in the form of droplets that have condensed from atmospheric water vapor and then precipitated - that is, become heavy enough to fall under gravity. Rain is a major component of the water cycle and is responsible for depositing most of the fresh water on the Earth. It provides suitable conditions for many types of ecosystem, as well as water for hydroelectric power plants and crop irrigation (Norman, 2008).

The major cause of rain production is moisture moving along three-dimensional zones of temperature and moisture contrasts known as weather fronts. If enough moisture and upward motion are present, precipitation falls from convective clouds (those with strong upward vertical motion) such as cumulonimbus (thunder clouds) which can organize into narrow rain bands (Udo et al 2002). In mountainous areas, heavy precipitation is possible where upslope flow is maximized within windward sides of the terrain at elevation which forces moist air to condense and fall out as rainfall along the sides of mountains. On the leeward side of mountains, desert climates can exist due to the dry air caused by down slope flow which causes heating and 
drying of the air mass. The movement of the monsoon trough, or intertropical convergence zone, brings rainy seasons to savannah climes (Paul, 2004).

Climate classification systems such as the Koppen climate classification system use average annual rainfall to help differentiate between differing climate regimes. Rainfall is measured using rain gauges. Rainfall amounts can be estimated by weather radar. Rain is also known or suspected on other planets, where it may be composed of methane, neon, sulfuric acid or even iron rather than water (Norman, 2008), (Udo et al 2002). Raindrops have sizes ranging from 0.1 to 9 millimeters mean diameter, above which they tend to break up. Smaller drops are called cloud droplets, and their shape is spherical. As a raindrop increases in size, its shape becomes more oblate, with its largest cross-section facing the oncoming airflow. Large rain drops become increasingly flattened on the bottom, like hamburger buns; very large ones are shaped like parachutes, Contrary to popular belief, their shape does not resemble a teardrop(Emmanuel et al 2009), (Alistair ,2003). The biggest raindrops on Earth were recorded over Brazil and the Marshall Islands in 2004 - some of them were as large as 10 millimetres. The large size is explained by condensation on large smoke particles or by collisions between drops in small regions with particularly high content of liquid water.( Paul, 2004). Rain drops associated with melting hail tend to be larger than other rain drops.( Norman, 2008).

Intensity and duration of rainfall are usually inversely related, i.e., high intensity storms are likely to be of short duration and low intensity storms can have a long duration (Udo et al 2002), (Ryan, 2005). Deviations can occur for small droplets and during different rainfall conditions. The distribution tends to fit averaged rainfall, while instantaneous size spectra often deviate and have been modeled as gamma distributions. (Houze et. al. 1979). The distribution has an upper limit due to droplet fragmentation (Emmanuel et al 2009). In view with (Afangideh et al 2013),

Rainfall intensity $(\mathrm{mm})=\frac{\text { annual rainfall amount }(\mathrm{mm})}{\text { annual rainfall duration (days) }}$

Raindrops impact at their terminal velocity, which is greater for larger drops due to their larger mass to drag ratio. At sea level and without wind, 0.5 millimetres drizzle impacts at 2 metres per second $(4.5 \mathrm{mph})(2$ $\mathrm{m} / \mathrm{s}$ or $6.6 \mathrm{ft} / \mathrm{s})$, while large 5 millimetre drops impact at around 9 metres per second $(20 \mathrm{mph})(9 \mathrm{~m} / \mathrm{s} \mathrm{or} 30 \mathrm{ft} / \mathrm{s})$. Rain falling on loosely packed material such as newly fallen ash can produce dimples that can be fossilized (Westhuizen et al 1989). The air density dependence of the maximum raindrop diameter together with fossil raindrop imprints has been used to constrain the density of the air 2.7 billion years ago (Som et al 2013). The sound of raindrops hitting water is caused by bubbles of air oscillating underwater(Andrea et al 1993; Rankin 2005),

Rainfall is a climate parameter that affects the way and manner man lives. It affects every facet of the ecological system, flora and fauna inclusive. Hence, the study of rainfall is important and cannot be over emphasized, (Osang et al 2013), (Obot et al 2010), (Ewona 2009). The study of rainfall distribution is also important in rain harvesting, agricultural production especially plant production. The seasonality of rainfall invariably affects crop and animal production. Storage of agricultural products, architectural designs, building and constructional, field work and tourism also depend on the seasonality of rainfall. The frequency and intensity of rainfall in a particular season results in seasonal floods (Obot et al 2010), (Osang et al 2013,).

\section{Effect Of Rainfall On Agriculture}

Precipitation, especially rain, has a dramatic effect on agriculture. All plants need at least some water to survive, therefore rain (being the most effective means of watering) is important to agriculture. While a regular rain pattern is usually vital to healthy plants, too much or too little rainfall can be harmful, even devastating to crops. Drought can kill crops and increase erosion, while overly wet weather can cause harmful fungus growth. Plants need varying amounts of rainfall to survive. For example, certain cacti require small amounts of water, while tropical plants may need up to hundreds of inches of rain per year to survive. Groundwater is a major source of water supply in the developed and developing countries which is caused by rain (Agbor et al 2013). In areas with wet and dry seasons, soil nutrients diminish and erosion increases during the wet season. Animals have adaptation and survival strategies for the wetter regime. The previous dry season leads to food shortages into the wet season, as the crops have yet to mature. Developing countries have noted that their populations show seasonal weight fluctuations due to food shortages seen before the first harvest, which occurs late in the wet season. Rain may be harvested through the use of rainwater tanks; treated to potable use or for non-potable use indoors or for irrigation. Excessive rain during short periods of time can cause flash floods (Udo et al 2002). 
Cultural attitudes towards rain differ across the world. In temperate climates, people tend to be more stressed when the weather is unstable or cloudy, with its impact greater on men than women. Rain can also bring joy, as some consider it to be soothing or enjoy the aesthetic appeal of it. In dry places, such as India, or during periods of drought, rain lifts people's moods. In Botswana, the Setswana word for rain, "pula", is used as the name of the national currency, in recognition of the economic importance of rain in this desert country. Several cultures have developed means of dealing with rain and have developed numerous protection devices such as umbrellas and raincoats, and diversion devices such as gutters and storm drains that lead rains to sewers. Many people find the scent during and immediately after rain pleasant or distinctive. The source of this scent is petrichor, an oil produced by plants, then absorbed by rocks and soil, and later released into the air during rainfall (Obot et al 2010), (Ewona et al 2008), .

\section{Effect Of Rainfall On Buildings Due To Flooding:}

Flooding may follow heavy rainfall, although floods can also follow from tidal surges and rapid snow melt. Flooding of low-lying lands caused by rise in sea level secondary to melting of the ice caps is also likely to happen. Of all the types of natural disaster world-wide, flooding is the commonest and can cause enormous damage and financial loss. No one in the Nigeria will be unaware of the floods of recent years and the suggestion that flood events are likely to increase in future (Hunter 2003), (Obot et al 2010). The health effects of flooding can be divided into those associated with the acute event and those arising after the flood has resolved. The main acute threat to health is drowning. In the Nigeria, deaths from drowning as a result floods is high. A high number people are killed each year by floods, although most concerns about subsequent health risk tends to focus on infectious disease, the evidence is relatively scant, at least for developed countries (Obot et al 2010), (Udo et al 2002). The impact that heavy rainfall on the genesis of outbreaks of disease associated with drinking water systems has already been discussed. In general these outbreaks have been associated with flows of contaminated water into the groundwater or the interference with the effectiveness of water treatment, (Hunter 2003)..

A direct relationship was observed between malaria transmission and monthly rainfall. Considers the potential impact on human health from waterborne and vector-borne infections. It concentrates on the impact of two possible changes to climate;increased frequency of heavy rainfall events, with associated flooding and increased temperature. Flooding is associated with increased risk of infection in developing nations but not in the West unless water sources arecompromised. There have been numerous reported of outbreaks that followed flooding that led to contamination of underground sources of drinking water. Heavy rainfall also leads to deterioration in the quality of surface waters that could adversely affect the health of those engaged in recreational water contact (Obot et al 2010), (Udo et al 2002). It is also concluded that there may be an increase in the number of cyanobacterial blooms because of a combination of increased nutrient concentrations and water temperature. It is considered unlikely that climate change will lead to an increase in disease linked to mains drinking water, although private supplies would be at risk from increased heavy rainfall events, (Odongo et al 2005), (Hunter 2003).

Fig. 1: showing pregnant-woman-6-others-drown-in-calabar-flood 2013.

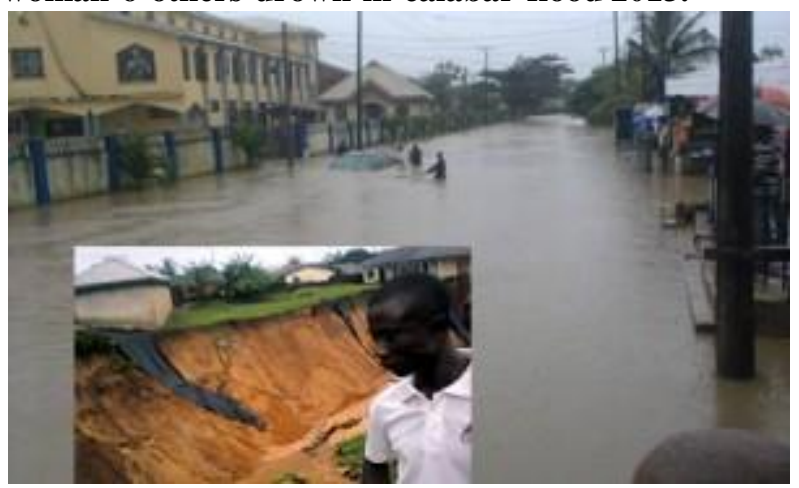

source: http://www.vanguardngr.com/2013/09/downpour-pregnant-woman-6-others-drown-in-calabarflood

\section{The Effect Of Rainfall On Human Health}

The human and economic costs associated with declining quality of life, consultations, treatments, hospitalisation and other events related to malaria are enormous and often lead to low productivity and lost incomes. In Cross River State in south-eastern Nigeria, malaria is such a significant problem among school children that the state government decided to involve them fully in the implementation of the RBM programme 
( Ndifreke et al 2010). Analysis of the medical conditions associated with fever indicates that malaria was the infection precursory for a third of all the fever cases among under 13 years old children for 12 years at General Hospital Calabar(Emmanuel et al 2013).

This is because school children are known to easily imbibe and implement new knowledge and can, therefore easily act as change agents and as role models for their siblings and peers. Malaria is a recognized public health problem globally, accounting for about 300 million clinical cases yearly in health facilities worldwide (WHO, 2000),(WHO, 2008). It is also responsible for more than one million deaths annually, with majority of the deaths occurring in sub-Saharan Africa (WHO, 2008). Malaria causes considerable morbidity and is a leading cause of hospital attendance in resource limited countries. It account for up to $40 \%$ of public health expenditures and a decrease of the gross domestic products of many African countries by as much as $1.3 \%$ annually (WHO, 2000). In Nigeria, it is responsible for loss of about 132 billion naira (US \$ 880 million) annually to treatment cost, loss of man-hours, school absenteeism and other indirect costs (Federal Ministry of Health, Nigeria, 2005) (Emmanuel et al 2013). This study thus sought to investigate the malaria knowledge and prevention practices among school adolescents in a coastal community in Calabar, Cross River State, Nigeria. (Ndifreke et al 2010)

\section{Study Area}

\section{Materials And Method}

Calabar is the capital of Cross River State. It is located at the Southern part of Cross River State. Calabar is located between longitudes $8^{0} 17^{\prime} 00 \mathrm{E}$ and $8^{0} 20^{\prime} 00^{\prime \prime} \mathrm{E}$ latitudes $4^{0} 50^{\prime} 00^{\prime \prime} \mathrm{N}$ and $5^{0} 10^{\prime} 00^{\prime \prime} \mathrm{N}$. Calabar metropolis comprises of Calabar Municipality and Calabar South Local Government Areas and covers an area of about 1,480 Sq km. Calabar is sandwiched between the Great Kwa River to the East and the Calabar River to the West. The presence of urban area is on the eastern bank of the Calabar River;its growth to the south is hindered by the mangrove swamps.

Calabar falls within tropical equatorial climate with high temperature, high relative humidity and abundant annual rainfall. Two major air masses affect the climate of Calabar as well as other contiguous locations in the West African region. The Tropical Maritime (mT) and the tropical continental (cT) air masses affect the climate in two distinct seasons. $\mathrm{mT}$ air prevails and influences its moisture characteristic while the cT air influences the dry season condition due to is desert source across the two air masses at the upper troposphere from east to west. This is called the Equatorial Esterlies (EE). The two air masses meet at the pressure front called Inter Tropical Discontinuity (ITD). There have been a massive development and urban expansion in the area over the last 10 years. This development is not without repercussions on the natural environment as lands that were formally vegetated, used for agriculture and as habitat for biodiversity are now being used for residential, commercial and industrial purposes to accommodate the growing population and businesses. The loss of once vegetated land implies a corresponding alteration of the micro-climate of the area which in turn has great impact on the long term climatic averages of the area (Afangideh et al 2013), (Osang et al 2013).

\section{Data Source}

Data was gathered through a well designed and articulated oral and written questionnaires, direct and firsthand observation of the environment, and comprehensive interview sessions were carried out with randomly selected Landlords . A total of thirteen thousand (13,000) questionnaires were randomly distributed evenly to some Landlords in twenty six (26) streets of the study Area from January 2012 to October 2013. Twelve thousand four hundred and eigty two $(12,482)$ valid questionnaire were received back. Twelve thousand $(12,000)$ of the inhabitant Landlords reported that, they were not affected negatively. Table 2 shows the total number of buildings that were negatively affected due to flooding in the Area. While rainfall data from 19932012 were collected from the Nigerian Meteorological Agency (NIMET), Margaret Ekpo International Airport, Calabar. A simple descriptive analysis was used 


\section{Result:}

Table 1: Data for rainfall per year in Calabar (1993-2012)

\begin{tabular}{|c|c|c|c|c|c|c|c|c|c|c|c|c|c|}
\hline YEAR & $\mathrm{JAN}$ & FEB & MARCH & APRIL & MAY & תNE & $\begin{array}{c}\pi L \\
Y\end{array}$ & AUG & $\begin{array}{c}\text { SEP } \\
\mathrm{T}\end{array}$ & OCT & NOV & $\mathrm{DEC}$ & $\begin{array}{c}\text { Average } \\
\text { value }\end{array}$ \\
\hline 1993 & 64.3 & 39.9 & 177.7 & 161.2 & 230.1 & 281 & 272.4 & 479.1 & 420.5 & 242.6 & 119.7 & 22.8 & 209.3 \\
\hline 1994 & 40.7 & 0 & 167.3 & 328.2 & 255.3 & 249.2 & 609.5 & 424.5 & 290 & 265.2 & 229.7 & 0 & 238.3 \\
\hline 1995 & TR & 21.1 & 366.1 & 248.3 & 208.6 & 375.2 & 632.4 & 467.4 & 696.8 & 496.1 & 168 & 69.7 & 306.6 \\
\hline 1996 & 2.4 & 162.2 & 161.5 & 314.5 & 299.5 & 435.3 & 401.1 & 425.1 & 615.2 & 357.4 & 40.5 & 0.6 & 269.7 \\
\hline 1997 & 61 & 0 & 139.4 & 228.1 & 328.2 & 633.1 & 796.6 & 492.6 & 211.2 & 319.1 & 212.3 & 68.2 & 290.8 \\
\hline 1998 & 25.4 & 6 & 174 & 149.1 & 211.6 & 504.5 & 255.2 & 353.7 & 365 & 437.1 & 396.3 & 33.6 & 242.6 \\
\hline 1999 & 86 & 49.8 & 223 & 311.4 & 180 & 270.3 & 349.9 & 494.5 & 368.3 & 463.7 & 207.3 & 0.3 & 250.4 \\
\hline 2000 & 66 & 0 & 951.9 & 166.4 & 217 & 250.6 & 597.9 & 392 & 577.6 & 232.9 & 153.6 & 57.5 & 305.3 \\
\hline 2001 & 0 & 11.6 & 151.7 & 371.8 & 419.4 & 390.5 & 268.5 & 457 & 455.7 & 381 & 217.1 & 5.7 & 260.8 \\
\hline 2002 & 0 & 13.5 & 154.6 & 383.3 & 301.3 & 344.6 & 274.1 & 623.5 & 284.3 & 285.8 & 126 & 6.8 & 233.2 \\
\hline 2003 & 26.7 & 103.2 & 226.6 & 283 & 315.3 & 202.2 & 327.4 & 398.6 & 399.2 & 224.1 & 148.5 & 2.9 & 5 \\
\hline 2004 & 9.9 & 19.9 & 73.5 & 278.4 & 270.2 & 308 & 303.5 & 391.9 & 335.5 & 196.4 & 168.3 & 0.6 & 196.3 \\
\hline 2005 & 33.8 & 35.5 & 295.7 & 299.9 & 263.9 & 615.6 & 828.2 & 634.4 & 230.4 & 279.8 & 182.3 & 71.5 & .3 \\
\hline 2006 & 84.7 & 57.1 & 323 & 166.1 & 430.8 & 227.7 & 484.9 & 273.4 & 536 & 175.3 & 134.4 & 0.1 & 1.1 \\
\hline 2007 & 0 & 51.1 & 181 & 265.9 & 384.2 & 583.5 & 492.7 & 415.5 & 561.7 & 197.4 & 262.1 & 33.1 & 285.7 \\
\hline 2008 & 15.1 & 1 & 108.1 & 216.9 & 386.8 & 437 & 597.7 & 509.2 & 217.9 & 315 & 105.1 & 77.1 & 248.9 \\
\hline 2009 & 89.7 & 38.5 & 87.5 & 150.5 & 308.9 & 218.4 & 577.4 & 507.3 & 273.9 & 148.1 & 126.9 & 0 & 210.6 \\
\hline 2010 & 31.8 & 88.2 & 63.6 & 130.4 & 306.5 & 611.3 & 384 & 406.7 & 451.3 & 269.6 & 272.1 & 56.2 & 256.0 \\
\hline 2011 & TR & 153.4 & 123.1 & 208.8 & 340.9 & 388.6 & 468.6 & 573.7 & 251.8 & 519.9 & 235.2 & 43.8 & 275.7 \\
\hline 2012 & 32.6 & 376.7 & 36 & 99.9 & 439.4 & 398.8 & 637.1 & 861.3 & 619.4 & 410.4 & 126.5 & 30.6 & 339.1 \\
\hline
\end{tabular}

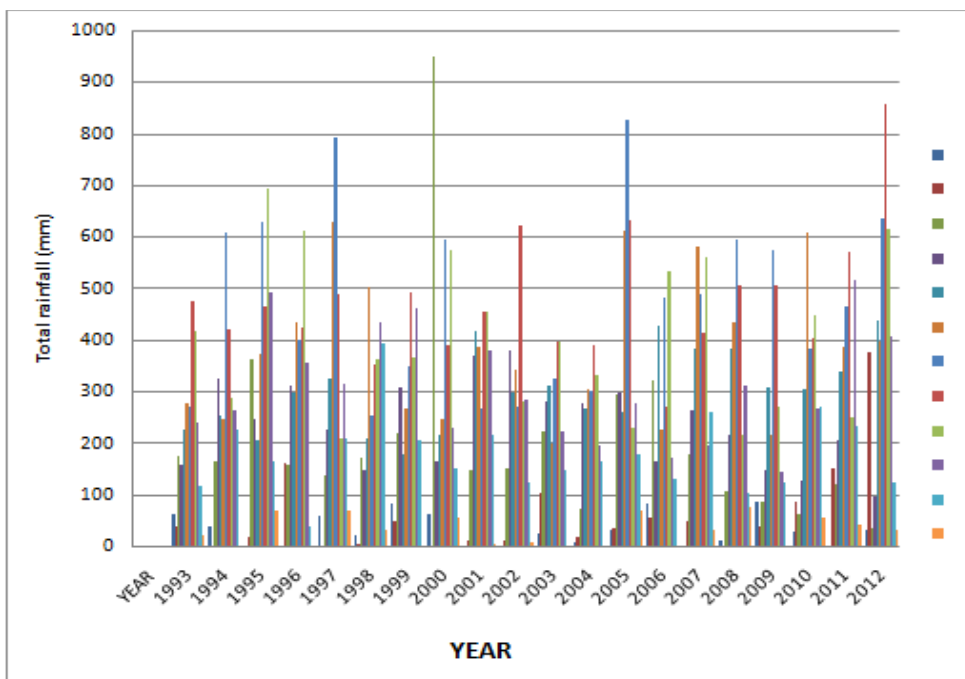

Fig 1 : Graph of total rainfall per year in calabar within the period of study. 
An Empirical Study Of Seasonal Rainfall Effect In Calabar, Cross River State, Nigeria.

Table 2: Total number of affected buildings due to flooding in Calabar from January 2012 to October 2013

\begin{tabular}{|c|c|c|c|}
\hline \multirow{2}{*}{$S / N$} & DISCRIPTION OF SELECETD & $\begin{array}{l}\text { TOTAL NUMBER } \\
\text { LANDLORD }\end{array}$ & $\begin{array}{lll}\text { TOTAL } & \text { NO. } & \text { OF } \\
\text { AFFECTED } & & \\
\text { BUILDING } & \text { DUE } & \text { TO }\end{array}$ \\
\hline & STREETS IN CALABAR & INTERVIEWED PER STREET & $\begin{array}{l}\text { BUIDONING DUE } \\
\text { FLOODING }\end{array}$ \\
\hline 1 & ATIMBO & 500 & 25 \\
\hline 2 & $\begin{array}{ll}\text { MORETALA } & \text { MOHAMMED } \\
\text { HIGH WAY } & \\
\end{array}$ & 500 & 24 \\
\hline \begin{tabular}{|l}
3 \\
\end{tabular} & NDIDEM USANG ISO & 500 & $\mid 21$ \\
\hline$\lcm{4}$ & GOLDIE & 500 & $\mid 21$ \\
\hline 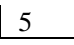 & EDIM OTOP & 500 & $\mid 23$ \\
\hline 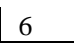 & EKPO ABASI & 500 & $\mid 21$ \\
\hline$\square$ & GOLDIE & 500 & 20 \\
\hline $\mid 8$ & TARGET & 500 & $\mid 21$ \\
\hline 9 & EBITO & 500 & $\mid 9$ \\
\hline$\lfloor 10$ & BIG QUA & 500 & $\mid 7$ \\
\hline \begin{tabular}{|l}
11 \\
\end{tabular} & EDIBE EDIBE & 500 & 17 \\
\hline \begin{tabular}{|l}
12 \\
\end{tabular} & ATAMUNU & 500 & $\mid 19$ \\
\hline \begin{tabular}{|l}
13 \\
\end{tabular} & AKIM ROAD & 500 & 8 \\
\hline \begin{tabular}{|l}
14 \\
\end{tabular} & I.BB WAY & 500 & $\mid 20$ \\
\hline 15 & OTOP ABASI & 500 & 21 \\
\hline \begin{tabular}{|l}
16 \\
\end{tabular} & PARLIAMENTARY ROAD & 500 & $\mid 19$ \\
\hline $\mid 17$ & $\begin{array}{ll}\text { IKOT } & \text { EYO } \\
\text { PARLIAMENTARY ROAD } & \text { BY } \\
\end{array}$ & 500 & $\mid 11$ \\
\hline $\mid 18$ & AMIKA UTUK & 500 & 20 \\
\hline \begin{tabular}{|l}
19 \\
\end{tabular} & WAT MARKET & 500 & 15 \\
\hline$\lfloor 20$ & MARIAN MARKET & 500 & $\mid 12$ \\
\hline $\mid 21$ & ASUQUO EKPO & 500 & $\mid 21$ \\
\hline 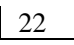 & OYO EFFIOM & 500 & $\mid 21$ \\
\hline 23 & EFFIOM ENE & 500 & 22 \\
\hline 24 & WHITE HOUSE & 500 & 22 \\
\hline 25 & MAPLE & 500 & 21 \\
\hline 26 & UWANSE & 500 & 21 \\
\hline & $\mathrm{TC}$ & 000 & 82 \\
\hline
\end{tabular}

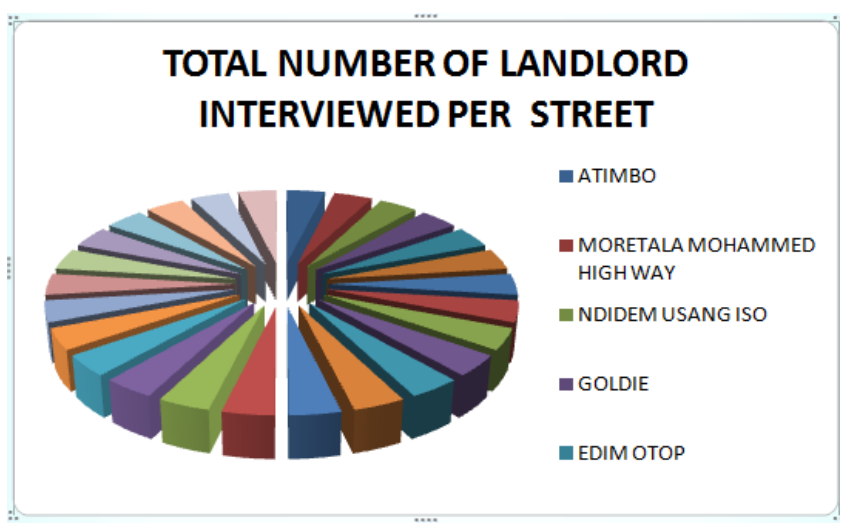

Fig 2 : pie chart showing total number inhabitant Landlord, street affected Area in calabar from January 2012 to October 2013 


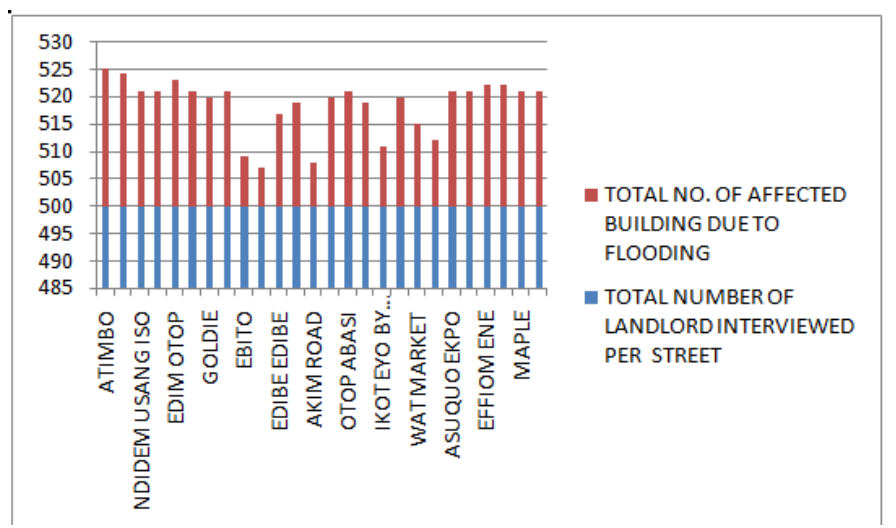

Fig 3 : comparism bar chart showing total number affected buildings due to flooding in calabar from January 2012 to October 2013

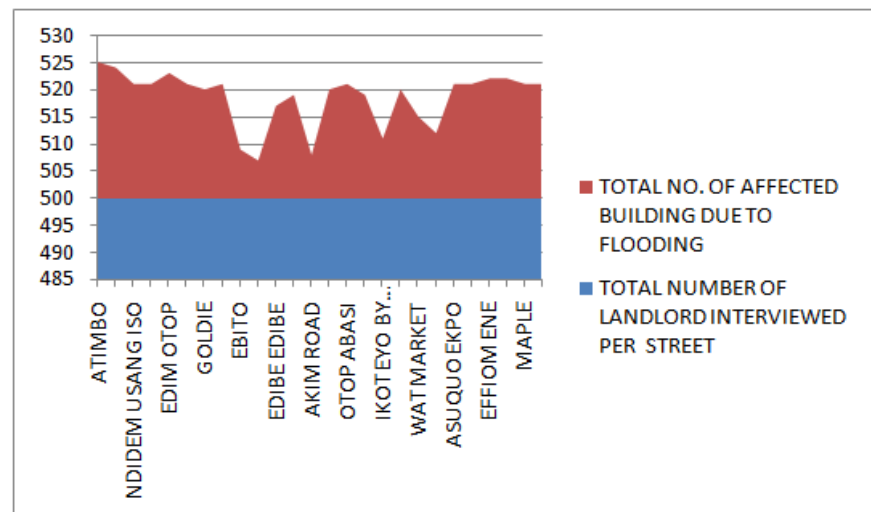

Fig 4 :chart showing total land Area of affected streets in calabar from January 2012 to October 2013

\section{Discussion:}

From Table 1 and fig 1(graph), it shows that total rainfall per year varies inconsistently over the year. The highest total rainfall $(\mathrm{mm})$ was recorded/observed in 2000. This is a year were various out break of disease like malaria was recorded within the study area (Emmanuel et al 2013). Total rainfall drops in 2001, 2002, 2003, and 2004, but a tremendiuos increase was observed in 2005 which also increase the statistics of malaria victims in the metropolise under study as stated by (Emmanuel et al 2013). between 2005 and 2011 there was fluctuation in the average rainfall(fig 1 and table 1), but minimal. In 2012 an increase in total rainfall was observed and this came with disaster we have not yet forgotten like flooding, outbreake of malaria,distruction of farm lands, displacement of residence etc.

Nevertheless, the total rainfall increase to its peak during the humid tropical climate of the region(between April and october) such trait is therfore expected as we observe more degredation/deplession in the ozone layer causing increase in global warming. It has been observed that this trend of rainfall partern will increase due to human influence on climate through growths and development in urban infrastructure, increase in population density of the study area and fossile fuel consumption etc

\section{Summary, Conclussion And Recomendation:}

A negative trend or decline in the annual rainfall regime may also be extended and viewed to encompass probable changes in the duration, intensity, frequency and the spread for the sub-region. These change response stimuli, including the rainfall amount, focused in the study constitute the entire components of rainfall changes that is potentially harmful to sensitive human systems in the long and short term. It is recommended therefore that follow-up studies aimed at identifying other response stimuli/lus other than the declining figures is required. Such a holistic approach may equally lead to a holistic solution to the disaster. Capacity building of human operators of sensitive systems e.g. the agricultural and health sub-sectors etc be initiated by all governments as stitch-in-time measures. Amongst other things, the ability to respond or cope is known to be a function of the awareness level, income and education. So greater awareness through education that seems totally lacking and skills through extension services education of peasants in particular need to be enhanced for informed and efficient reactions. Finally, an intergraded impact study to determine the multiple effect of human development on the annual rainfall regime is strongly advocated. Besides providing a scientific management framework 
through its modeling and projections. The integrated impact assessment approach normally suggests adaptation policy options.

Conceptually, human culture gets affected, modified \& sustained over years and years. Such changes in the personality traits is therefore expected. It is rainfall that determines the nature of the society's culture \& civilisation. Rainfall fundamentally decides the flora of a habitat thereby the fauna to follow. Humans as they have a greater degree of dependancy on both, get their physical \& cultural environment affected. Rainfall causes the following: (1.) Flooding, which may eliminate habitat for both humans and Aquatic hosts thereby force vertebrate hosts into closer contact with humans. (2.) Decrease in survival of humans due to lost of lives. (3.) Negative changes in human population growth. (4.) Changes in feeding behavior. (5.) Changes in seasonality of Human activities. (6.) Increase rate of diseases like malaria, fiver etc. (7.) Destruction of buildings and infracstructure (8.) Destruction of crops due to heavy rain. (9.) Destruction of Animal homes due to flooding. (10.) Increase of accidents rate due to bad roads caused by flooding.

With the current available evidence and scenarios for climate Change due to rainfall effect in Calabar, it would appear that the public health effects injunction with the Government, various establishment and agency concern with health effects through rainfall pattern should contributes positively to keep the Environment safe for a healthy living haven known all its consequences.

\section{Reference}

[1]. AFANGIDEH,A.I; EKPE, I. A. \& OFFIONG, R. A.: IMPLICATIONS OF CHANGING RAINFALL PATTERN ON BUILDING LOSS IN CALABAR; www.seahipub.org . retrieved 3:12 pm 9/11/2013

[2]. Agbor R.B., Ekpo I.A., Ekaluo U.B., Okpako E.C., Okigbo A.U., Osang, J.E., Kalu S.E; Groundwater Quality Assessment Of Some Selected Boreholes In Calabar; World Rural Observations 2013;5(3) http://www.sciencepub.net/rural

[3]. $\quad$ Alistair B. Fraser (2003-01-15). "Bad Meteorology: Raindrops are shaped like teardrops.". Pennsylvania State University. Retrieved 2008-04-07.

[4]. $\quad$ Andrea Prosperetti and Hasan N. Oguz (1993). "The impact of drops on liquid surfaces and the underwater noise of rain" (PDF). Annual Review of Fluid Mechanics 25: 577-602. Bibcode:1993AnRFM..25.577P. doi:10.1146/annurev.fl.25.010193.003045. Retrieved 2006-12-09.

[5]. CARS-SUBMERGED http://www.vanguardngr.com/2013/09/downpour-pregnant-woman-6-others-drown-incalabar-flood; . retrieved 1:22 am 2/11/2013

[6]. E Odongo-Aginya, G Ssegwanyi, P Kategere and P C Vuzi: Relationship between malaria infection intensity and rainfall pattern in Entebbe peninsula, Uganda: Afr Health Sci. 2005 September; 5(3): 238-245.

[7]. Emmanuel C. Uttah, Hannah Etta Cletus, Iboh Raymond Ajang, George I. Ukpong; Fever among Children in Calabar, Nigeria: Malaria, the Predominant Precursory Medical Condition; Journal of Biology, Agriculture and Healthcare www.iiste.org ISSN 22243208 (Paper) ISSN 2225-093X (Online)Vol.3, No.8, 2013.

[8]. $\quad$ Emmanuel Villermaux, Benjamin Bossa (September 2009). "Single-drop fragmentation distribution of raindrops.". Nature Physics 5 (9): 697-702. Bibcode: $2009 \mathrm{NatPh} . . .5 . .697 \mathrm{~V}$. doi: $10.1038 / \mathrm{NPHYS} 1340$. Lay summary

[9]. Ewona I. O. and Udo, S. O. (2008) Characteristic Pattern of Rainfall in Calabar, Nigeria - a Tropical Location Nigeria. Nig. Journal of Physics 20 (1), 84-91.

[10]. Ewona I. O. and Udo, S. O. (2008) Characteristic Pattern of Rainfall in Calabar, Nigeria - a Tropical Location Nigeria. Nig. Journal of Physics 20 (1), 84-91.

[11]. EWONA, I. O., OSANG, J. E, OBI, E. O., UDOIMUK A. B., USHIE, P. O.: AIR QUALITY AND ENVIRONMENTAL HELATH IN CALABAR, CROSS RIVER STATE, NIGERIA:(2013): IOSR Journal Of Environmental Science, Toxicology And Food Technology (IOSR-JESTFT) e-ISSN: 2319-2402,p- ISSN: 2319-2399. Volume 6, Issue 6 (Nov. - Dec. 2013), PP 55-65 www.iosrjournal.org

[12]. Falling raindrops hit 5 to $20 \mathrm{mph}(8.0$ to $32 \mathrm{~km} / \mathrm{h})$ speeds". Weather Quest. Retrieved 2008-04-08

[13]. Houze, Robert A., Peter V. Hobbs, Paul H. Herzegh, David B. Parsons, 1979: Size Distributions of Precipitation Particles in Frontal Clouds. J. Atmos. Sci., 36, 156-162. doi: http://dx.doi.org/10.1175/1520-0469 (1979)036 <0156:SDOPPI>2.0.CO;2

[14]. http://onlinelibrary.wiley.com/doi/10.1046/j.1365-2672.94.s1.5.x/pdf

[15]. http://www.ncbi.nlm.nih.gov/pmc/articles/PMC1831935; Retreaved 10:51, 19/11/2013.

[16]. Igwe O. Ewona and Sunday O. Udo (2009) Seasonal and Long, Term Rainfall Trend in Calabar Nigeria; Global Journal of Pure and Applied Sciences Vol. 15 No. 2 (2009) $247-254$.

[17]. Igwe O. Ewona and Sunday O. Udo (2009) Seasonal and Long, Term Rainfall Trend in Calabar Nigeria; Global Journal of Pure and Applied Sciences Vol. 15 No. 2 (2009) $247-254$.

[18]. International Journal of Innovative Environmental StudiesResearch 1 (2):10-18,September2013@ SEAHI PUBLICATIONS, 2013 www.seahipub.org . retrieved 3:12 pm 9/11/2013

[19]. Louis E. Akpabio, Sunday O. Udo, Sunday E. Etuk; Empirical Correlations of Global Solar Radiation with Meteorological Data for Onne, Nigeria. Turk J Phys 28 (2004) 205-212.

[20]. Marshall, J. S. \& Palmer, W. M. The distribution of raindrops with size. J. Meteorol. 5, 165-166 (1948).

[21]. N. I. Obot, M. A. Chendo, S. O. Udo and I. O. Ewona (2010) Evaluation of Rainfall Trends in Nigeria for 30 Years (1978-2007) International Journal of the Physical Sciences Vol. 5(14), PP 2217 - 22224 Nov. 2010

[22]. N. I. Obot, M. A. Chendo, S. O. Udo and I. O. Ewona (2010) Evaluation of Rainfall Trends in Nigeria for 30 Years (1978-2007) International Journal of the Physical Sciences Vol. 5(14), PP 2217 - 22224 Nov. 2010

[23]. Ndifreke E. Udonwa, Abraham N. Gyuse, Aniekan J. Etokidem; Malaria: Knowledge and prevention practices among school adolescents in a coastal community in Calabar, Nigeria; African Journal of Primary Health Care and Family Medicine; PHCFM Vol 2, No 1 (2010); http://www.phcfm.org/index.php/phcfm/article/view/103/66

[24]. Niu, Shengjie, Xingcan Jia, Jianren Sang, Xiaoli Liu, Chunsong Lu, Yangang Liu, 2010: Distributions of Raindrop Sizes and Fall Velocities in a Semiarid Plateau Climate: Convective versus Stratiform Rains. J. Appl. Meteor. Climatol., 49, 632-645. doi: http://dx.doi.org/10.1175/2009JAMC2208.1 
[25]. Norman W. Junker (2008). "An ingredients based methodology for forecasting precipitation associated with MCS's". Hydrometeorological Prediction Center. Retrieved 2009-02-07.

[26]. OBI, E. O., OSANG, J. E., EWONA, I. O., UDOIMUK A. B., KAMGBA, F. A. (2013):, Environmental health Effect and Air Pollution from cigarette smokers in Cross River State, Nigeria; IOSR Journal of Applied Physics (IOSR-JAP) e-ISSN: 2278-4861. Volume 4, Issue 6 (Sep. - Oct. 2013), PP 61-68; www.iosrjournal.org

[27]. Osang, J. E., Udoimuk, A. B., Etta, E. B., Ushie, P. O., Offiong N. E. Methods of Gathering Data for Research Purpose and Applications Using IJSER Acceptance Rate of Monthly Paper Publication (March 2012 Edition-May 2013 Edition) IOSR Journal of Computer Engineering (IOSR-JCE) e-ISSN: 2278-0661, p- ISSN: 2278-8727Volume 15, Issue 2 (Nov. - Dec. 2013), PP 59-65 www.iosrjournals.org

[28]. Osang, J.E, Obi E.O, Ewona, I.O Udoimuk A.B, Nnwankukwu. (2013) Review of Gas flaring Activities in Nigeria Delta Area of Nigeria. International Journal of Scientific and Engineering Research http://www.ijsetr.org. Volume 4, Issue 9, September 2013 Edition; http://www.ijsetr.org

[29]. Osang, Jonathan Eyire, Obi, Emmanuel O. and Ewona, Igwe O; Evaluation of the effect of workshop/laboratory accidents and precautionary steps towards safety practice. IOSR Journal of Electronics and communication Engineering (IOSR-JECE) eISSN:2278-2834, P-ISSN:2278-8735. Volume 6 issue 3 (May=June 2013) pp 16-22. www.iosrjournal.org

[30]. Osang. J. E., Ewona, I.O, Obi E. O., Udoimuk A,B, Kamgba F.A.,(2013); Analyses of Radiation and Rainfall pattern in Kano State Northern Nigeria (1978-2007), International Journal of Scientific \& Engineering Research, Volume 4, Issue 9, September2013 971ISSN 2229-5518 : http://www.ijser.org.

[31]. P.R. Hunter; Climate change and waterborne and vector-borne disease: Journal of Applied Microbiology 2003,94, 37S-46S;

[32]. Paul Rincon (2004-07-16). "Monster raindrops delight experts". British Broadcasting Company. Retrieved 2009-11-30.

[33]. Peter AO Odjugo; An analysis of rainfall patterns in Nigeria; http://www.ajol.info/index.php/gjes/article/view/2455 retrieved 2:22 pm 29/10/2013.

[34]. RatnayakeU.Herath S. (2005). Changing Rainfall and its Impacts on Landslides in Sri-Lanka J. Mov. Sci. 2(3): 218 - 224.

[35]. Ryan C. Rankin (June 2005). "Bubble Resonance". The Physics of Bubbles, Antibubbles, and all That. Retrieved 2006-12-09.

[36]. S.O. Udo, O.E.Ani and K. Oduro-Afriye; Effect of Moisture and bulk density on soil temperature Global Journal of pure and Applied Science vol. 8, No. 1 January 2002. 125-132

[37]. Som, Sanjoy M., Catling, David C., Harnmeijer, Jelte P., Polivka, Peter M., Buick, Roger. Air density 2.7 billion years ago limited to less than twice modern levels by fossil raindrop imprints. Nature. 484: 7394 p. 359-362. http://dx.doi.org/10.1038/nature10890

[38]. Studies on meteorological parameters and mixing height in Gold mining http://article.sapub.org/10.5923.j.re 201220205.06.html. Retrieved 2/22/2013..

[39]. Symmetronhttp://symmetrongr/en index.php?cat.Retrieved 2/22/2013 7:30pm.

[40]. W.A. van der Westhuizen, N.J. Grobler, J.C. Loock, E.A.W. Tordiffe, Raindrop imprints in the Late Archaean-Early Proterozoic Ventersdorp Supergroup, South Africa, Sedimentary Geology, Volume 61, Issues 3-4, February 1989, Pages 303-309, ISSN 00370738, http://dx.doi.org/10.1016/0037-0738(89)90064-X. (http://www.sciencedirect.com/science/article/pii/003707388990064X)

[41]. World Health Organization. (2000). Overcoming Antimicrobial Resistance; W.H.O report on infectious diseases.WHO publication. 21-28 WHO/CDS.

[42]. World Health Organization. (2008). World Malaria Report. Switzerland: www.collinsmap.com accessed June 2012. 